\title{
11. ORIGIN OF UPPER CRETACEOUS MULTICOLORED CLAYSTONES OF THE WESTERN ATLANTIC
}

\author{
Michael A. Arthur, Department of Geological and Geophysical Sciences, Princeton University, \\ Princeton, New Jersey ${ }^{1}$
}

Widespread deposition of organic-carbon-rich black shale and related sediment in most of the western North Atlantic Basin ended by late Cenomanian time. The anoxic or near-anoxic deep-water conditions which initially led to preservation of the black shale facies ceased rather abruptly, perhaps consequent to onset of an effective deep circulation which promoted oxygenation in deep-water settings. Cores show that Upper Cretaceous sediments directly overlying the black shale facies are generally "red" or "multicolored" clay. These non-calcareous upper Cenomanian to lower Maestrichtian(?) claystones, which contain no fossils, probably represent slow deposition under well-oxygenated conditions and a high CCD (Tucholke and Vogt, this volume).

The multicolored claystones are mineralogically similar to the Red Sea hot brine deposits, as pointed out by Lancelot et al., 1972. However, they differ chemically (Table 1, Figure 1) from the Red Sea Deposits, as well as from typical iron- and manganeserich basal sediments of actively spreading mid-ocean ridges (e.g., the East Pacific Rise). They also differ from other "metal"-enriched sedimentary deposits related to the alteration of volcanics or to hydrothermal activity (Jenkyns and Hardy, 1976; Natland, 1973). Chemically, the multicolored claystones resemble modern pelagic red clays, although on the average they contain more iron and less manganese than red clays and have somewhat lower concentrations of trace elements.

These multicolored claystones possess certain other characteristics which differentiate them from the normal pelagic "red" clays covering much of the sea floor today. Color banding, with vivid yellow, orange, olivegreen, white, black, and red-brown, is common. The colors occur in beds of varying thickness ( $\mathrm{mm}$ to $\mathrm{dm}$ ). Zeolites (mainly clinoptilolite), montmorillonite, abundant ferric hydroxides, and iron-manganese micronodules are typical mineral constituents. Silty layers of sphalerite and iron-manganese spherules or micronodules also serve to distinguish the Cretaceous claystones from the average red clay facies of today (see Lancelot et al., 1972, and this volume for a more complete description of the Upper Cretaceous claystones).

In order to explain the mineralogy and chemistry of the multicolored claystones, Lancelot et al. (1972)

lPresent address: Scripps Institute of Oceanography, La Jolla, California. likened them to either the iron- and manganeseenriched basal sediments documented along the actively spreading East Pacific Rise (e.g., as described by Böstrom and Peterson, 1969; Böstrom et al., 1969; Sayles and Bischoff, 1973; Piper, 1973), or to metalenriched sediments associated with the Red Sea hot brines (e.g., Bischoff, 1969; Hendricks et al., 1969). They concluded that volcanic or hydrothermal exhalations superimposed on slow rates of pelagic clay deposition could account for the color banding and mineralogical variations described above. This would involve periodic precipitation of iron and manganese hydroxides and sphalerite from the water column above, resulting from enrichment by exhalative processes. Vogt (1972) also suggests that the metal content in the Upper Cretaceous claystones is related to increased plume activity in the Atlantic at the time of their deposition.

However, a widespread increase in volcanic-hydrothermal exhalations may not be needed to explain the overall mineralogical and geochemical attributes of the multicolored claystones, and I propose instead the following hypothesis for their origin: a large reservoir of chemically reduced metallic ions existed in the anoxic pore waters of the thick black shale section below the claystones; these ions were mobilized, diffused upward, and precipitated rapidly in the oxidized zone of the slowly accumulating Upper Cretaceous clays.

Many modern deep-sea examples of manganeseand iron-enrichments in oxidized surface pelagic sediments seem best explained as results of upward diffusion of dissolved species from chemically reduced sediment (e.g., Lynn and Bonatti, 1965; Li et al., 1969; Calvert and Price, 1972; Bonatti et al., 1971; see also Crerar and Barnes, 1974; and Elderfield, in press, for review). The solubility of manganese and to some extent of nickel and cobalt in interstitial waters is controlled by redox reactions. Manganese seems to be most mobile under reducing conditions (Bonatti et al., 1971; Michard, 1971; Spencer and Brewer, 1971; Manheim, 1965); iron concentrations may be primarily dependent on dissolved sulfide concentrations and secondarily on carbonate alkalinity in anoxic environments (Berner, 1971; Bonatti et al., 1971). There are a few detailed chemical studies of interstitial waters of anoxic sediments, but existing data (e.g., Brooks et al., 1968; Presley et al., 1972; Nissenbaum et al., 1972; Bonatti et al., 1971) demonstrate that significant amounts of manganese and iron, as well as certain 
TABLE 1

Averages (wt.\%) on a Carbonate-Free Basis of Various Deep-Sea Clays, Including Metalliferous Types

\begin{tabular}{|c|c|c|c|c|c|c|c|c|c|c|c|c|c|c|}
\hline \multirow{2}{*}{$\begin{array}{c}\text { Sediment } \\
\text { Type and } \\
\text { Source }\end{array}$} & \multirow[b]{2}{*}{$\mathrm{Mn}$} & \multirow[b]{2}{*}{$\mathrm{Fe}$} & \multirow[b]{2}{*}{$\mathrm{Ti}$} & \multicolumn{4}{|c|}{$\begin{array}{c}\text { Concentration } \\
\mathrm{Wt} . \% ; \mathrm{CaCO}_{3} \text {-free }\end{array}$} & \multirow[b]{2}{*}{$\mathrm{Cr}$} & \multirow[b]{2}{*}{$\mathrm{Zn}$} & \multirow[b]{2}{*}{$\mathrm{Al}$} & \multirow[b]{2}{*}{$\mathrm{Fe} / \mathrm{Mn}$} & \multirow[b]{2}{*}{$\mathrm{Mn} / \mathrm{Al}$} & \multirow[b]{2}{*}{$\mathrm{Fe} / \mathrm{Al}$} & \\
\hline & & & & $\mathrm{Ni}$ & Co & $\mathrm{Cu}$ & Mo & & & & & & & \\
\hline A & 0.367 & 5.54 & 0.509 & 0.0296 & 0.0098 & 0.0439 & 0.0015 & 0.0058 & - & 10.08 & 15.1 & .04 & .55 & \multirow{3}{*}{ Average, Pacific Red Clays } \\
\hline B & 0.706 & 5.06 & 0.568 & 0.0256 & 0.0111 & 0.0515 & 0.0043 & 0.0162 & - & 9.30 & 7.2 & .08 & 1.8 & \\
\hline $\mathrm{C}$ & 0.478 & 5.07 & 0.455 & 0.0211 & 0.0101 & 0.0323 & 0.0018 & 0.0102 & - & - & 10.6 & - & - & \\
\hline $\mathrm{D}$ & 1.8 & 5.15 & - & 0.0210 & 0.0150 & 0.0560 & - & - & 0.0085 & 8.3 & 2.9 & .22 & .62 & $\begin{array}{l}\text { Average, Pacific Cretaceous Metallif- } \\
\text { erous Sediments (Basal) }\end{array}$ \\
\hline $\mathrm{E}$ & 0.39 & 8.59 & 1.14 & 0.0050 & 0.033 & 0.0139 & - & 0.0095 & - & 5.68 & 22.0 & .07 & 1.5 & \\
\hline $\mathrm{F}$ & 6.0 & 18.0 & 0.02 & 0.0430 & 0.0105 & 0.0730 & - & - & 0.0380 & 0.5 & 3.0 & 12.0 & 36.0 & \\
\hline G & 2.4 & 9.5 & 0.17 & 0.0690 & 0.0215 & 0.0990 & - & - & 0.0285 & 4.7 & 4.0 & 0.51 & 2.0 & erous Sediments \\
\hline $\mathrm{H}$ & 3.71 & 13.5 & 0.09 & 0.1004 & 0.0198 & 0.0979 & - & - & 0.0321 & 2.34 & 3.6 & 1.6 & 5.8 & \\
\hline I & 0.91 & 9.5 & - & - & - & $<0.01$ & - & - & 0.14 & 9.3 & 10.4 & 0.05 & 1.0 & \\
\hline $\mathrm{J}$ & 1.8 & 31.8 & - & - & - & 0.79 & - & - & 3.2 & 1.1 & 17.7 & 1.6 & 28.9 & Red Sea Hot Brine Deposits \\
\hline $\mathrm{K}$ & 0.79 & 44.9 & - & - & - & 0.24 & - & - & 0.56 & 0.58 & 56.8 & 1.4 & 77.4 & $\begin{array}{l}\text { (Individual Facies) } \\
\text { (n) }\end{array}$ \\
\hline $\mathrm{L}$ & 0.91 & 19.5 & - & - & - & 4.1 & - & - & 11.3 & 0.91 & 21.4 & 1.0 & 21.4 & \\
\hline M & 25.6 & 21.3 & - & - & - & 0.08 & - & - & 1.1 & 0.37 & 0.83 & 69.2 & 57.6 & \\
\hline $\mathrm{N}$ & 0.22 & 6.35 & 0.53 & 0.0177 & 0.0026 & 0.0152 & 0.0018 & 0.0145 & - & 10.02 & 28.9 & 0.02 & 0.63 & Atlantic Cretaceous Multicolored \\
\hline $\mathrm{O}$ & 0.30 & 4.73 & 0.29 & - & - & $0.0071^{\mathrm{a}}$ & - & - & - & $7.01^{b}$ & 15.8 & 0.04 & 0.67 & Claystones \\
\hline
\end{tabular}

Note: A = El Wakeel and Riley (1961) 8 samples Pacific red clay; B = Goldberg and Arrhenius (1958) 13 samples Pacific red clay; C = Cronan (1969) 54 samples Pacific red clay (non-metalliferous); D = Landergren (1964) average samples Pacific red clay; E = Jenkyns and Hardy (1976), DSDP Leg 33, Cretaceous Site 315 basal metal. seds.; F = Böstrom and Peterson (1969) average samples metalliferous seds, high heat flow, East Pacific Rise; G = Böstrom and Peterson (1969) average samples, average to low heat flow, East Pacific Rise; H = Sayles and Bischoff (1973) averages 8 samples ferro-manganese sediments, East Pacific Rise; I-M = Bischoff (1969) averages 5 mineralogic facies in Red Sea hot brine deposits, 43 samples total: (I) detrital; (J) Fe-montmorillonite; (K) geothite-amorphous; (L) sulfide; (M) manganite (2 analyses only); $\mathrm{N}=\mathrm{Lancelot}$ et al. (1972), averages 24 samples multicolored clay facies, Site 105, DSDP Leg 11, Cretaceous Atlantic; O = Murdma et al., this volume averages 14 samples red and multicolored clay facies, DSDP Leg 43, Cretaceous Atlantic.

${ }^{\mathrm{a}}$ Based on only 2 samples.

${ }^{b}$ Based on 10 samples.

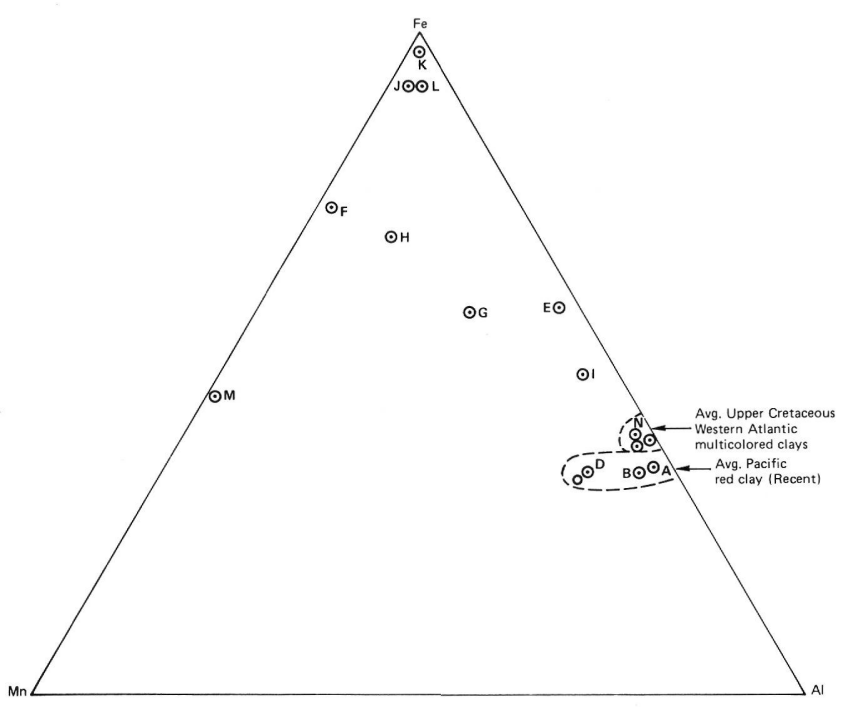

Figure 1. Fe-Mn-Al diagram of deep-sea sediments (Table 1) on a $\mathrm{CaCo}_{3}$-free basis; typical pelagic clays and metalenriched sediments represented (see Table 1 for key to localities and age).

trace metals, can be mobilized in a reduced form. I propose here that much of the excess iron and manganese in the Cretaceous multicolored claystones was derived by upward diffusion of dissolved ions, and also by advection of pore water from the compacting black shale sequence below. When the upward-diffusing, chemically reduced metallic ions reached a sufficiently oxygenated interface within the red clay zone, or at the sediment/water interface, rapid precipitation of iron and/or manganese hydroxides took place in consequence of drastically lowered solubilities under high Eh conditions (e.g., Berner, 1971; Crerar and Barnes, 1974; Bischoff, 1969). This explanation provides a mechanism for color banding and mineral differentia- tion. Because of the slightly higher solubility of manganese, it is likely that it would precipitate later than iron, thus creating successive layers of different chemical and mineralogical composition. The time involved (millions of years) and the overall compaction and upward migration of pore waters from below overcomes the objection of Elderfield (in press) concerning diffusion rates versus precipitation rates of manganese in vertical profiles. Although iron is usually not very mobile, owing to the dissolved sulfide control, as previously mentioned, there is evidence that abundant excess reduced iron existed in pore waters of the black shales. The presence of siderite at many levels in the black shales attests to the nearly total exhaustion of dissolved sulfide (Berner, 1971). Thus, even after siderite precipitation, iron was probably available for upward migration. Small-scale examples of color banding and metaloxide enrichment above anoxic sediment in deep-sea settings have been noted by Bartlett and Greggs (1970) in the Pleistocene of the Atlantic, by Sevastoyanov (1968) in the Pleistocene and Recent of the Mediterranean Sea (above thin sapropels), and by Berger and von Rad (1972) from mid-Cretaceous clays above organic-carbon-rich nannofossil marl ooze in the Atlantic (Site 136, DSDP Leg 14).

Upward movement of dissolved silica derived from dissolution of siliceous microfossils in the black shale section below may also have occurred, contributing to the formation of significant amounts of the zeolite clinoptilolite and perhaps montmorillonite in the lower part of the multicolored claystone (e.g., Site 105). There is no need to postulate alteration of volcanic components (there is no definite evidence of any having been present) to explain the zeolites or the montmorillonite. The presence of sphalerite, however, is an enigma, and I can offer no satisfactory explanation for its occurrence. It is especially concentrated near the base of the multicolored clays, nearest a possible 
source for sulfide in the organic-carbon-rich black shales, but the large amounts of zinc are baffling.

In conclusion, it is not necessary to assume a volcanic source for certain metals and mineral assemblages within the Upper Cretaceous multicolored claystones of the western Atlantic Basin. Diagenetic mobilization of redox-sensitive metals within anoxic pore waters of the Lower Cretaceous black shales and upward diffusion-advection into the oxidized claystones can account for the variable iron-manganese enrichment observed.

\section{ACKNOWLEDGMENTS}

I have benefited by discussion of many aspects of this problem with David Crerar, W. B. F. Ryan, and Brian Tucholke. David Crerar and A. G. Fischer reviewed an earlier version of this paper. The research was supported by NSF grant DES 74-22214.

\section{REFERENCES}

Bartlett, G. A. and Greggs, R. G., 1970. The Mid-Atlantic Ridge near $45^{\circ} 00^{\prime}$ north. VIII. Carbonate lithification on ocean ridges and seamounts: Canadian J. Earth Sci., v. 7, p. 257-267.

Berger, W. H. and von Rad, U., 1972. Cretaceous and Cenozoic sediments from the Atlantic Ocean: In Hayes, D. E., Pimm, A. C., et al., Initial Reports of the Deep Sea Drilling Project, v. 14: Washington (U. S. Government Printing Office), p. 787-954.

Berner, R. A., 1971. Principles of chemical sedimentology: New York (McGraw-Hill Inc.).

Bischoff, J. L., 1969. Red Sea geothermal brine deposits: their mineralogy, chemistry and genesis: In Degens, E. T. and Ross, D. A., (Eds.) Hot brines and recent heavy metal deposits in the Red Sea: New York (Springer Verlag), p. 368-401.

Bonatti, E., Fisher, D. E., Joensuu, O., and Rydell, H. S., 1971. Post-depositional mobility of some transition elements, phosphorous, uranium, and thorium in deep-sea sediments: Geochim. Cosmochim. Acta, v. 35, p. 189-201.

Böstrom, K. and Peterson, M. N. A., 1969. Origin of aluminum-poor ferromanganoan sediments in areas of high heat flow on the East Pacific Rise: Mar. Geol., v. 7, p. 427-447.

Böstrom, K., Peterson, M. N. A. Joensuu, O., and Fischer, D. E., 1969. Aluminum poor ferromanganoan sediments on active ocean ridges: J. Geophys. Res., v. 74, p. 3261-3269.

Brooks, R. R., Presley, B. J., and Kaplan, I. R., 1968. Trace elements in the interstitial waters of marine sediments: Geochim. Cosmochim. Acta., v. 32, p. 397-414.

Calvert, S. E. and Price, N. B., 1972. Diffusion and reaction profiles of dissolved manganese in the pore waters of marine sediments: Earth Planet. Sci. Lett., v. 16, p. 245249.

Crerar, D. A. and Barnes, H. L., 1974. Deposition of deepsea manganese nodules: Geochim. Cosmochim. Acta, v. 88, p. $279-300$.

Cronan, D. S. 1969. Average abundances of Mn, Fe, Ni, Co, $\mathrm{Cu}, \mathrm{Pb}, \mathrm{Mo}, \mathrm{V}, \mathrm{Ce}, \mathrm{Ti}$, and $\mathrm{P}$ in Pacific pelagic clays: Geochim. Cosmochim. Acta, v. 33, p. 1562-1565.

Elderfield, H., in press. The form of manganese and iron in marine sediments: In Glasby, G. P., (Ed.), Marine manganese deposits: Amsterdam (Elsevier).
El Wakeel, S. K. and Riley, J. P., 1961. Chemical and mineralogical studies of deep-sea sediments: Geochim. Cosmochim. Acta, v. 25, p. 110-146.

Goldberg, E. D. and Arrhenius, G. O. S., 1958. Chemistry of Pacific pelagic sediments: Geochim. Cosmochim. Acta., v. 13, p. 153-212.

Hendricks, R. L., Reisbick, F. B., Mahaffey, E. J., Roberts, D. B., and Peterson, M. N. A., 1969. Chemical composition of sediments and interstitial brines from the Atlantis II, Discovery and Chain deeps: In Degens E. T. and Ross, D. A., (Eds.), Hot brines and recent heavy metal deposits in the Red Sea: New York (Springer-Verlag), p. 407-440.

Jenkyns, H. C. and R. G. Hardy, 1976. Basal iron-titaniumrich sediments from Hole 315A (Line Islands, Central Pacific). In Schlanger, S. O., Jackson, E. D., et al., Initial Reports of the Deep Sea Drilling Project, v. 33: Washington (U. S. Government Printing Office), p. 833836.

Lancelot, Y., Hathaway, J. C., and Hollister, C. D., 1972. Lithology of sediments from the Western North Atlantic Leg 11 Deep Sea Drilling Project. In Hollister, C. D., Ewing, J. I., et al., Initial Reports of the Deep Sea Drilling Project, v. 11: Washington (U. S. Government Printing Office), p. 901-949.

Landergren, S., 1964. On the geochemistry of deep-sea sediments: Rep. Swedish Deep-Sea Exped., X., Spre Invest., v. 5, p. 1-154.

Li, Y, Bischoff, J. L., and Mathieu, G., 1969. The migration of manganese in the Arctic Basin sediment: Earth Planet. Sci. Lett., v. 7, p. 265-277.

Lynn, D. C. and Bonatti, E., 1965. Mobility of manganese in diagenesis of deep-sea sediments: Mar. Geol., v. 3, p. 457474.

Manheim, F. T., 1965. Manganese-Iron accumulations in the shallow-marine environment: Occl. Publ. 3, Narragansett Marine Lab., Univ. Rhode Island, p. 217-276.

Michard, G., 1971. Theoretical model for manganese distribution in calcareous sediment cores: J. Geophys. Res., v. 76 , p. $2179-2186$.

Natland, J. H., 1973. Basal ferromanganoan sediments at DSDP Site 183, Aleutian abyssal plain, and Site 192, Meiji Guyot, northwest Pacific, Leg 19. In Creager, J. S., School, D. W., et al., Initial Reports of the Deep Sea Drilling Project, v. 19: Washington (U. S. Government Printing Office), p. 629-640.

Nissenbaum, A., Presley, B. J., and Kaplan, I. R., 1972. Early diagenesis in a reducing fjord, Saanich Inlet, B.C.-I. chemical and isotopic changes in major components of interstitial water: Geochim. Cosmochim Acta, v. 36, p. 1007-1027.

Piper, D. Z., 1973. Origin of metalliferrous sediments from the East Pacific Rise: Earth Planet. Sci. Lett., v. 19, p. 7582.

Presley, B. J., Kolodny, Y., Nissenbaum, A., and Kaplan, I. R., 1972. Early diagenesis in a reducing fjord, Saanich Inlet, B.C.-II. trace elements distribution in interstitial water and sediments: Geochim. Cosmochim. Acta., v. 36, p. 1073-1090.

Sayles, F. L. and Bischoff, J. L., 1973. Ferromanganoan sediments in the Equatorial East Pacific: Earth Planet. Sci. Lett., v. 19, p. 330-336.

Sevastyanov, V. F., 1968. Redistribution of chemical elements as a consequence of oxidation-deoxidation processes in sediments of the Mediterranean Sea: Litologia-i-Poleznye Iskopayeme, v. 1, p. 3-15.

Spencer, D. W. and Brewer, P. G., 1971. Vertical advection diffusion and redox potentials as controls on the distribu- 
tion of manganese and other trace metals dissolved in waters of the Black Sea: J. Geophys. Res., v. 76, p. 58775892.
Vogt, P. R., 1972. Evidence for global synchronism in Mantle Plume Convection, and possible significance for geology: Nature, v. 240, p. 338-342. 